\title{
SOLUSI PERSAMAAN KESEIMBANGAN MASSA REAKTOR MENGGUNAKAN METODE PEMISAHAN VARIABEL
}

\author{
${ }^{1}$ Moh. Syaiful Arif, ${ }^{2}$ Mohammad Jamhuri \\ 1Jurusan Matematika, Universitas Islam Negeri Maulana Malik Ibrahim Malang \\ 2jurusan Matematika, Universitas Islam Negeri Maulana Malik Ibrahim Malang \\ Email: arif.ipoel@gmail.com
}

\begin{abstract}
ABSTRAK
Persamaan keseimbangan massa reaktor menyatakan perubahan konsentrasi massa zat yang masuk dan keluar pada sistem tertutup. Persamaan ini mempunyai kondisi batas tak homogen, yaitu kondisi pada saat zat masuk pada reaktor $\left(C_{i n}\right)$ dan kondisi pada saat zat keluar dari reaktor $\left(C_{\text {out }}\right)$. Pada penelitian ini, konsentrasi massa zat yang dihasilkan setelah proses reaksi di dalam reaktor adalah nol, atau $C_{\text {out }}=0$. Pada kondisi batas tak homogen, dengan menggunakan metode pemisahan variabel, terdapat kendala untuk menyelesaikan persamaan tersebut. Sehingga perlu dilakukan transformasi terlebih dahulu. Transformasi dilakukan dengan tujuan untuk mengubah kondisi batas yang awalnya tak homogen menjadi kondisi batas yang homogen, sehingga metode pemisahan variabel dapat digunakan untuk menyelesaikan persamaan diferensial parsial yang mempunyai kondisi batas homogen. Hasil analisa diperoleh, semakin cepat zat yang menyebar pada reaktor, maka semakin sedikit jumlah konsentrasi massa zat yang mengalami perubahan, semakin besar koefisien massa zat yang bereaksi dalam reaktor, maka semakin banyak jumlah konsentrasi massa zat yang mengalami perubahan
\end{abstract}

Kata kunci: kondisi batas homogen, kondisi batas tak homogen, metode pemisahan variabel.

\begin{abstract}
Mass balance of reactor equation express the change of mass concentration of substances in and out of the closed system. This equation has inhomogeneous boundary conditions, that is the conditions at the time of its entry to the reactor $\left(C_{i n}\right)$ and the conditions under which the substance out of the reactor $\left(C_{\text {out }}\right)$. In this study, the mass concentration of substances produced after the reaction in the reactor is zero, or $C_{\text {out }}=0$. In the inhomogeneous boundary conditions, using the method of separation of variables, there are obstacles to complete the equation. So we need to first transformation. Transformation is done with the aim to change the conditions which originally inhomogeneous boundary into a homogeneous boundary condition, so the method of separation of variables can be used to solve partial differential equations that have a homogeneous boundary conditions. The results obtained by the analysis, the faster a substance that spreads to the reactor, the less amount of mass concentration of substances that undergo a change; the greater the mass coefficient of substances that react in the reactor, the more the number of mass concentration of substances that are subject to change
\end{abstract}

Keywords: homogeneous boundary condition, inhomogeneous boundary condition, method of separation of variabel.

\section{PENDAHULUAN}

Hukum kekekalan massa adalah suatu hukum yang menyatakan bahwa massa pada suatu sistem tertutup tidak akan berubah meskipun terjadi berbagai macam reaksi didalam sistem tersebut. Tempat atau alat yang digunakan selama proses reaksi disebut reaktor [1].

Hukum kekekalan massa umumnya digunakan pada bidang kimia industri. Hukum kekekalan massa dapat dinyatakan sebagai keseimbangan suatu massa zat yang masuk dan keluar dari sistem tertutup (reaktor). Keseimbangan massa pada reaktor terjadi apabila akumulasi massa zat di dalam reaktor sama dengan selisih antara massa zat yang masuk dengan massa zat yang keluar serta massa yang dihasilkan di dalam sistem tertutup (Caldwell, 2004). Kondisi tersebut, dalam ilmu matematika diformulasikan menjadi bentuk persamaan diferensial parsial linier yang disebut dengan persamaan keseimbangan massa reaktor. Sehingga untuk menganalisa permasalahan tersebut, cukup dengan cara mencari solusi 
penyelesaian dari persamaan keseimbangan massa reaktor.

Salah satu metode yang digunakan untuk memperoleh solusi analitik persamaan diferensial parsial adalah metode pemisahan variabel. Metode ini dilakukan dengan cara memisahkan masingmasing variabel independent dengan suatu fungsi dan konstanta pemisahan, atau disebut dengan fungsi eigen dan nilai eigen [2]. Kemudian dengan menggunakan kondisi batas homogen, masingmasing fungsi eigen dan nilai eigen dapat ditentukan.

Akan tetapi, pada kondisi batas tak homogen terdapat kendala untuk menentukan fungsi eigen dan nilai eigen, dengan demikian perlu dilakukan transformasi yang bertujuan untuk mengubah kondisi batas tak homogen menjadi kondisi batas homogen. Sehingga fungsi yang sudah dipisahkan tersebut dapat diselesaikan secara terpisah. Oleh karena itu, penelitian ini bermaksud menentukan solusi analitik untuk model keseimbangan massa reaktor yang dipengaruhi oleh perubahan waktu dengan kondisi batas tak homogen menggunakan metode pemisahan variabel.

\section{KAJIAN TEORI}

\section{Persamaan Keseimbangan Massa Reaktor}

Persamaan keseimbangan massa reaktor menyatakan perubahan konsentrasi massa zat yang masuk dan keluar pada sistem tertutup [1].

[3] menyebutkan bahwa perubahan konsentrasi massa zat di dalam sistem tertutup atau reaktor, dinyatakan dalam persamaan berikut:

$$
\begin{aligned}
\frac{\partial C(x, t)}{\partial t}= & D \frac{\partial^{2} C(x, t)}{\partial x^{2}}-U \frac{\partial C(x, t)}{\partial x} \\
& -\gamma C(x, t)
\end{aligned}
$$

dengan kondisi awal dan kondisi batas yang digunakan yaitu:

$\left\{\begin{array}{l}C(x, 0)=0,0<x<l \\ C(0, t)=C_{\text {in }}, \quad C(l, t)=0, \quad t>0\end{array}\right.$

Pada persamaan (1) dan (2), $C_{\text {in }}$ adalah menyatakan massa zat yang masuk pada suatu reaktor dengan satuan $\mathrm{mol} / \mathrm{m}^{3}, D$ menyatakan koefisien penyebaran zat dengan satuan $\mathrm{m}^{2} /$ det, $U$ menyatakan kecepatan fluida yang mengalir dalam reaktor dengan satuan $m /$ det, sedangkan $\gamma$ adalah koefisien reaksi dengan satuan $\mathrm{mol} /$ det.

\section{Persamaan Diferensial Biasa}

Persamaan diferensial biasa merupakan suatu persamaan yang menyatakan relasi fungsi, yang mempunyai satu peubah dengan turunan fungsi terhadap peubah tersebut. Dengan demikian turunan fungsi dinotasikan dengan suatu operator $d$ [4].

\section{Persamaan Diferensial Parsial}

Persamaan diferensial parsial merupakan suatu persamaan yang menyatakan relasi antara suatu fungsi dependent dengan variabel independent yang lebih dari satu variabel beserta turunan parsialnya [5].

[4] menggunakan notasi $\partial$ sebagai operator persamaan diferensial parsial. Untuk menyederhanakan penulisan, turunan parsial bisa dinotasikan $\frac{\partial C(x, t)}{\partial x}=C_{x}(x, t), \frac{\partial^{2} C(x, t)}{(\partial x)^{2}}=C_{x x}(x, t)$, dan seterusnya [2].

Suatu persamaan diferensial parsial disebut linier apabila terdapat suatu operator diferensial $\mathcal{L}$ yang diterapkan pada fungsi $\mathrm{C}$, sehingga berlaku

$$
\mathcal{L} C=g
$$

Pada persamaan (3), apabila $g=0$ maka disebut sebagai persamaan diferensial parsial linier homogen. Sedangkan apabila $g \neq 0$, maka disebut sebagai persamaan diferensial parsial linier tak homogen [5]. Dengan demikian, persamaan keseimbangan massa reaktor (1) merupakan persamaan diferensial parsial linier homogen.

\section{Kondisi Batas Homogen dan Kondisi Batas Tak Homogen}

Misalkan $C(x, t)$ adalah solusi dari suatu persamaan diferensial parsial pada batas $0<x<$ $l$, kondisi batas pada saat $x=0$ dan $x=l$ dituliskan seperti persamaan berikut:

$$
\begin{aligned}
& C(0, t)=g(t) \\
& C(l, t)=h(t)
\end{aligned}
$$

Persamaan (4) dan (5) merupakan contoh kondisi batas Dirichlet. Apabila $g(t)=0$ dan $h(t)=0$ maka disebut sebagai kondisi batas homogen. Sedangkan apabila $g(t) \neq 0$ atau $h(t) \neq$ 0 , maka disebut sebagai kondisi batas tak homogen [5].

\section{Metode Pemisahan Variabel}

Salah satu metode yang digunakan untuk memperoleh solusi persamaan diferensial parsial linier adalah metode pemisahan variabel. Metode ini dilakukan dengan cara memisahkan masingmasing variabel independent dengan suatu fungsi yang mengandung variabel independent dan konstanta pemisahan. Masing-masing fungsi dan konstanta pemisahan disebut sebagai fungsi eigen dan nilai eigen [2].

Misalkan $\mathrm{C}(x, t)=X(x) T(t)$ adalah solusi dari suatu persamaan diferensial parsial, maka $X(x)$ merupakan fungsi eigen yang memuat variabel $x$, sedangkan $T(t)$ adalah fungsi eigen yang memuat variabel $t$. Sehingga masing-masing 
fungsi eigen dapat diselesaikan secara terpisah [6].

Pada kondisi batas homogen, untuk menentukan nilai eigen dapat dilakukan dengan cara mensubstitusikan kondisi batas pada masingmasing fungsi yang sudah diselesaikan secara terpisah [2]. Sedangkan pada kondisi batas tak homogen terdapat kendala untuk menentukan nilai eigen. Sehingga penyelesaian persamaan diferensial parsial yang mempunyai kondisi batas tak homogen dapat dilakukan dengan cara mentransformasikan kondisi batas yang awalnya tak homogen diubah menjadi homogen [5].

\section{Deret Fourier}

[2] menyebutkan bahwa, misalkan terdapat domain $x$ pada suatu interval $0<x<l$, sedemikian sehingga terdapat suatu deret sinus yang konvergen menuju suatu fungsi $\phi(x)$ yang didefinisikan seperti persamaan berikut:

$$
\phi(x)=\sum_{n=1}^{\infty} A_{n} \sin \left(\frac{n \pi x}{l}\right)
$$

Pada persamaan (6), $A_{n}$ merupakan koefisien deret sinus, sedangkan $\phi(x)$ adalah suatu fungsi tertentu. Dengan demikian nilai $A_{n}$ dapat ditentukan seperti berikut:

$$
\begin{array}{ll}
A_{n}= \begin{cases}0, & n \neq m \\
\frac{2}{l} \int_{0}^{l} \phi(x) \sin \left(\frac{n \pi x}{l}\right) d x, & n=m\end{cases} \\
\text { PEMBAHASAN }
\end{array}
$$

\section{PEMBAHASAN}

Pada bab sebelumnya telah dijelaskan, terdapat kendala dalam menyelesaikan persamaan keseimbangan massa reaktor (1) yang mempunyai kondisi batas tak homogen (2). Sehingga perlu dilakukan transformasi kondisi batas, yang awalnya tak homogen diubah menjadi kondisi batas homogen. Sehingga solusi persamaan keseimbangan massa reaktor ditrasformasikan seperti berikut:

$$
C(x, t)=V(x, t)+C(x)
$$

Dari persamaan (2), dapat diketahui bahwa kondisi batas yang digunakan $C(0, t)$ dan $C(l, t)$ adalah kondisi batas tak homogen, sehingga $V$ mempunyai kondisi batas homogen apabila kondisi batas yang digunakan $C(0)$ dan $C(l)$ sama dengan kondisi batas yang digunakan $C(0, t)$ dan $C(l, t)$, atau ditulis $C(0)=C_{\text {in }}$ dan $C(l)=0$. Fungsi $C(x)$ merupakan suatu fungsi yang hanya bergantung pada variabel $x$ saja. Hal ini dikarenakan apabila fungsi $C(x)$ hanya bergantung pada variabel $x$ dan $t$, mengakibatkan kondisi batas $V$ tidak homogen. Dengan demikian, transformasi (8) dapat menjamin $C(x, t)$ merupakan solusi persamaan keseimbangan massa reaktor yang mempunyai kondisi batas tak homogen.

Dari penjelasan di atas, $C(x)$ merupakan solusi persamaan keseimbangan massa reaktor pada kondisi laju perubahan konsentrasi massa tidak dipengaruhi oleh perubahan waktu (steadystate). Sehingga untuk memperoleh solusi pada persamaan (8), perlu diselesaikan persamaan keseimbangan massa reaktor pada kondisi steadystate seperti berikut:

$$
D \frac{d^{2} C(x)}{d x^{2}}-U \frac{d C(x)}{d x}-\gamma C(x)=0
$$

Persamaan (9) merupakan persamaan diferensial biasa homogen orde dua. Sehingga apabila $U^{2}+4 D \gamma>0$ maka solusi $C(x)$ mempunyai akar-akar real berbeda, apabila $U^{2}+$ $4 D \gamma=0$ maka solusi $C(x)$ mempunyai akar-akar kembar, sedangkan apabila $U^{2}+4 D \gamma<0$ maka solusi $C(x)$ mempunyai akar-akar komploks. diperoleh

Pada kondisi $U^{2}+4 D \gamma>0$ solusinya

$C(x)=k_{1} e^{\left(\frac{U+\sqrt{U^{2}+4 D \gamma}}{2 D}\right) x}+k_{2} e^{\left(\frac{U-\sqrt{U^{2}+4 D \gamma}}{2 D}\right) x}$

dengan menggunakan kondisi batas $C(0)=$ $C_{\text {in }}$ dan $C(l)=0$, maka nilai $k_{1}$ dan $k_{2}$ dapat diperoleh:

$$
\begin{gathered}
k_{1}=\frac{C_{i n} e^{\left(\frac{U-\sqrt{U^{2}+4 D \gamma}}{2 D}\right) l}}{\left.\operatorname{dan}^{\left(\frac{U-\sqrt{U^{2}+4 D \gamma}}{2 D}\right) l}-e^{\left(\frac{U+\sqrt{U^{2}+4 D \gamma}}{2 D}\right)}\right)} \\
k_{2}=-\frac{C_{i n} e^{\left(\frac{U+\sqrt{U^{2}+4 D \gamma}}{2 D}\right) l}}{\left.e^{\left(\frac{U-\sqrt{U^{2}+4 D \gamma}}{2 D}\right) l}-e^{\left(\frac{U+\sqrt{U^{2}+4 D \gamma}}{2 D}\right)}\right)}
\end{gathered}
$$

Pada kondisi $U^{2}+4 D \gamma=0$, dengan cara yang sama, solusinya diperoleh

$$
C(x)=C_{i n} e^{\frac{U}{2 D} x}-\frac{C_{\text {in }}}{l} x e^{\frac{U}{2 D} x}
$$

Sedangkan pada kondisi $U^{2}+4 D \gamma<0$, dengan cara yang sama, solusinya diperoleh

$$
\begin{aligned}
C(x)= & C_{i n} e^{\frac{U}{2 D} x} \cos \left(\frac{\sqrt{\left|U^{2}+4 D \gamma\right|}}{2 D} x\right) \\
& +k_{4} e^{\frac{U}{2 D} x} \sin \left(\frac{\sqrt{\left|U^{2}+4 D \gamma\right|}}{2 D} x\right)
\end{aligned}
$$


dengan $k_{4}=-C_{i n} \cot \left(\frac{\sqrt{\left|U^{2}+4 D \gamma\right|}}{2 D} l\right)$

Selanjutnya, untuk menjamian solusi $V(x, t)$ memenuhi persamaan keseimbangan massa reaktor, maka persamaan (8) disubstiusikan pada persamaan (1), sehingga dapat diperoleh persamaan baru seperti berikut:

$$
V_{t}(x, t)=D V_{x x}(x, t)-U V_{x}(x, t)-\gamma V(x, t)
$$

dengan mensubstitusikan kondisi batas $C(0, t)$, $C(l, t)$ dan $C(0), C(l)$ pada persamaan (8), maka kondisi batas $V$ pada saat $x=0$ dan $x=l$ adalah

$$
V(0, t)=0, \quad V(l, t)=0
$$

Sedangkan kondisi awal $V$ pada saat $t=0$ adalah

$$
V(x, 0)=-C(x)
$$

Langkah selanjutnya, $\quad V(x, t)$ dapat diperoleh dengan cara menyelesaikan persamaan (13). Sehingga dimisalkan

$$
V(x, t)=T(t) X(x)
$$

sebagai solusi dari persamaan (13). Kemudian dengan mensubstitusikan persamaan (16) pada (13), maka dapat diperoleh

$$
\begin{aligned}
& \frac{T^{\prime}(t)}{T(t)}=D \frac{X^{\prime \prime}(x)}{X(x)}-U \frac{X^{\prime}(x)}{X(x)}-\gamma \\
& \frac{T^{\prime}(t)}{T(t)}+\gamma=D \frac{X^{\prime \prime}(x)}{X(x)}-U \frac{X^{\prime}(x)}{X(x)}
\end{aligned}
$$

Pada persamaan (17), ruas kiri hanya bergantung pada variabel $t$, sedangkan ruas kanan hanya bergantung pada variabel $x$. Sehingga kondisi tersebut hanya dapat dipenuhi apabila kedua ruas bernilai konstanta yang tidak bergantung pada variabel $t$ dan $x$. Misalkan konstanta yang dimaksud adalah $\lambda$, maka persamaan (17) dapat dipisahkan menjadi seperti berikut:

$$
\begin{array}{r}
D \frac{X^{\prime \prime}(x)}{X(x)}-U \frac{X^{\prime}(x)}{X(x)}=\lambda \\
D X^{\prime \prime}(x)-U X^{\prime}(x)-\lambda X(x)=0
\end{array}
$$

dan

$$
\begin{array}{r}
\frac{T^{\prime}(t)}{T(t)}+\gamma=\lambda \\
T^{\prime}(t)-(\lambda-\gamma) T(t)=0
\end{array}
$$

Pada persamaan (18) dan (19), $\lambda$ adalah suatu konstanta, sehingga $\lambda$ dapat bernilai nol, positif, atau negatif, secara terurut dinotasikan dengan $\lambda=0, \lambda>0$, atau $\lambda<0$. Dengan demikian, untuk menentukan solusi dari persamaan (18) dan (19), ditentukan terlebih dahulu nilai $\lambda$ yang memenuhi. Untuk $\lambda=0$, maka solusi persamaan (18) adalah

$$
X(x)=m_{3}+m_{4} e^{\frac{U}{D} x}
$$

dengan menggunakan kondisi batas (14), maka dapat diperoleh $m_{3}=0$ dan $m_{4}=0$. Dengan demikian, untuk $\lambda=0$, solusi $X(x)$ adalah nol (trivial solution).

Untuk $\lambda>0$, dimisalkan $\lambda=\beta^{2}$ maka solusi persamaan (18) adalah

$$
X(x)=m_{5} e^{\frac{U+\sqrt{U^{2}+4 D \beta^{2}}}{2 D} x}+m_{6} e^{\frac{U-\sqrt{U^{2}+4 D \beta^{2}}}{2 D} x}
$$

dengan menggunakan kondisi batas (14), maka dapat diperoleh $m_{5}=0$ dan $m_{4}=0$. Dengan demikian, untuk $\lambda>0$, solusi $X(x)$ adalah nol (trivial solution).

Sedangkan untuk $\lambda<0$, dimisalkan $\lambda=$ $-\beta^{2}$ maka solusi persamaan (18) adalah

$$
X(x)=m_{7} e^{\frac{U+\sqrt{U^{2}-4 D \beta^{2}}}{2 D}} x+m_{8} e^{\frac{U-\sqrt{U^{2}-4 D \beta^{2}}}{2 D}} x
$$

Dari persamaan tersebut dapat diketahui bahwa, apabila $U^{2}-4 D \beta^{2}>0$, maka seperti pada kasus $\lambda>0$ solusinya adalah nol (trivial solution). Dengan demikian, nilai dipilih $U^{2}-$ $4 D \beta^{2}<0$. Artinya $U^{2}-4 D \beta^{2}$ harus bernilai negatif. Dengan demikian, $U^{2}-4 D \beta^{2}=$ $-\left(4 D \beta^{2}-U^{2}\right)$ dapat menjamin nilainya selalu negatif. Sehingga solusinya diperoleh

$$
\begin{aligned}
X(x) & =m_{7} e^{\frac{U+\sqrt{-\left(4 D \beta^{2}-U^{2}\right)}}{2 D} x}+m_{8} e^{\frac{U-\sqrt{-\left(4 D \beta^{2}-U^{2}\right)}}{2 D} x} \\
& =m_{7} e^{\frac{U+i \sqrt{4 D \beta^{2}-U^{2}}}{2 D} x}+m_{8} e^{\frac{U-i \sqrt{4 D \beta^{2}-U^{2}}}{2 D} x}
\end{aligned}
$$

Persamaan tersebut dapat diubah menjadi seperti berikut:

$$
\begin{aligned}
X(x)= & e^{\frac{U}{2 D} x}\left(m_{9} \cos \left(\frac{\sqrt{4 D \beta^{2}-U^{2}}}{2 D} x\right)\right) \\
& +e^{\frac{U}{2 D} x}\left(m_{10} \sin \left(\frac{\sqrt{4 D \beta^{2}-U^{2}}}{2 D} x\right)\right)
\end{aligned}
$$

dengan menggunakan kondisi batas (14), maka dapat diperoleh $m_{9}=0, m_{10} \neq 0$, dan $\beta=$ $\sqrt{\frac{(2 n \pi D)^{2}+U^{2} l^{2}}{4 D l^{2}}}$ untuk $n$ menuju tak hingga $(n=$ $1,2, \ldots)$. Sehingga solusi $X(x)$ dapat disederhanakan menjadi

$$
X(x)=m_{10} e^{\frac{U}{2 D} x} \sin \left(\frac{n \pi x}{l}\right)
$$

Dikarenakan nilai $\lambda$ yang memenuhi adalah $\lambda=-\beta^{2}$, maka solusi $T(t)$ dari persamaan (20) adalah

$$
T(t)=m_{12} e^{-\left(\frac{(2 n \pi D)^{2}+U^{2} l^{2}}{4 D l^{2}}+\gamma\right) t}
$$

Langkah selanjutnya, dengan mensubstitusikan persamaan (20) dan (21) pada 
persamaan (16), maka solusi $V(x, t)$ dapat diperoleh seperti berikut

$$
V(x, t)=\sum_{n=0}^{\infty} E_{n} e^{-\left(\frac{(2 n \pi D)^{2}+U^{2} l^{2}}{4 D l^{2}}+\gamma\right) t} e^{\frac{U}{2 D} x} \sin \left(\frac{n \pi x}{l}\right)
$$

$E_{n}$ merupakan suatu nilai yang dapat diperoleh dengan mensubstitusikan kondisi awal. Dari persamaan tersebut dapat diketahui pada saat $n=0$, mengakibatkan nilai dari $\sin (0)=0$, sehingga solusi $V(x, t)=0$. Dengan demikian pada saat $n=0$, nilai $E_{0}$ tidak mempengaruhi hasil dari penjumlahanya, jadi solusinya yaitu:

$$
V(x, t)=\sum_{n=1}^{\infty} E_{n} e^{-\left(\frac{(2 n \pi D)^{2}+U^{2} l^{2}}{4 D l^{2}}+\gamma\right) t} e^{\frac{U}{2 D} x} \sin \left(\frac{n \pi x}{l}\right)
$$

Kemudian dengan menggunakan kondisi awal (15), maka pada saat $t=0$ diperoleh

$$
-C(x)=\sum_{n=1}^{\infty} E_{n} \sin \left(\frac{n \pi x}{l}\right)
$$

dengan menggunakan ekspansi deret Fourier seperti persamaan (7), maka nilai $E_{n}$ dapat diperoleh seperti berikut:

$$
\mathrm{E}_{\mathrm{n}}=-\frac{2}{l} \int_{0}^{l} C(x) \sin \left(\frac{n \pi x}{l}\right) d x
$$

Kemudian dengan mengintegralkan persamaan tersebut, apabila $U^{2}+4 D \gamma>0$ diperoleh

$$
\begin{aligned}
& \mathrm{E}_{\mathrm{n}}= \\
& \frac{2 n \pi\left(k_{1}\left(e^{A_{1} l} \cos (n \pi)-1\right)+k_{2}\left(e^{-A_{1} l} \cos (n \pi)-1\right)\right)}{(n \pi)^{2}+\left(l A_{1}\right)^{2}} \\
& \text { dengan } A_{1}=\frac{\sqrt{\left|U^{2}+4 D \gamma\right|}}{2 D} . \text { Apabila } U^{2}+4 D \gamma=
\end{aligned}
$$

0 , maka $E_{n}=-\frac{2 C_{i n}}{n \pi}$. Sedangkan apabila $U^{2}+$ $4 D \gamma<0$, maka dapat diperoleh

$$
\begin{aligned}
E_{n}=\frac{C_{i n}\left(\left(\cos \left(A_{1} l+n \pi\right)-1\right)\right)+k_{3}\left(\sin \left(A_{1} l+n \pi\right)\right)}{\left(A_{1} l+n \pi\right)} & \\
- & -\frac{C_{\text {in }}\left(\left(\cos \left(A_{1} l-n \pi\right)-1\right)\right)+k_{3}\left(\sin \left(A_{1} l-n \pi\right)\right)}{\left(A_{1} l-n \pi\right)} .
\end{aligned}
$$

Substitusikan masing-masing solusi $C(x)$ dan $V(x, t)$ pada persamaan (14), maka solusi persamaan keseimbangan massa reaktor yang mempunyai kondisi batas tak homogen yaitu:

1. Jika $U^{2}+4 D \gamma>0$, maka diperoleh

$$
\begin{gathered}
C(x, t)= \\
\sum_{n=1}^{\infty} E_{n} e^{-\left(\frac{(2 n \pi D)^{2}+U^{2} l^{2}}{4 D l^{2}}+\gamma\right) t} e^{\frac{U}{2 D} x} \sin \left(\frac{n \pi x}{l}\right) \\
+k_{1} e^{\left(\frac{U+\sqrt{U^{2}+4 D \gamma}}{2 D}\right) x}+k_{2} e^{\left(\frac{U-\sqrt{U^{2}+4 D \gamma}}{2 D}\right) x}
\end{gathered}
$$

2. Jika $U^{2}+4 D \gamma=0$, maka diperoleh

$$
C(x, t)=\sum_{n=1}^{\infty} E_{n} e^{-\left(\frac{(2 n \pi D)^{2}+U^{2} l^{2}}{4 D l^{2}}+\gamma\right) t} e^{\frac{U}{2 D} x} \sin \left(\frac{n \pi x}{l}\right)
$$

$$
C_{\text {in }} e^{\frac{U}{2 D} x}-\frac{C_{i n}}{l} x e^{\frac{U}{2 D} x}
$$

3. Jika $U^{2}+4 D \gamma<0$, maka diperoleh

$$
\begin{array}{r}
C(x, t)= \\
\sum_{n=1}^{\infty} E_{n} e^{-\left(\frac{(2 n \pi D)^{2}+U^{2} l^{2}}{4 D l^{2}}+\gamma\right) t} e^{\frac{U}{2 D} x} \sin \left(\frac{n \pi x}{l}\right) \\
+C_{i n} e^{\frac{U}{2 D} x} \cos \left(\frac{\sqrt{\left|U^{2}+4 D \gamma\right|}}{2 D} x\right) \\
+k_{4} e^{\frac{U}{2 D} x} \sin \left(\frac{\sqrt{\left|U^{2}+4 D \gamma\right|}}{2 D} x\right)
\end{array}
$$

Setelah solusi persamaan keseimbangan massa reaktor diperoleh, maka untuk mengetahui perubahan konsentrasi massa zat di sepanjang reaktor, ditentukan parameternya terlebih dahulu. Misalkan masing-masing parameternya ditentukan seperti berikut: $C_{\text {in }}=100 \mathrm{~mol} / \mathrm{m}^{3}$, $U=0.008 \mathrm{~m} /$ det, $\gamma=0.018 \mathrm{~mol} / \mathrm{det}$, kemudian penyebaran zat yang awalnya $D=0.083 \mathrm{~m}^{2} / \mathrm{det}$ dipercepat menjadi $D=0.8 \mathrm{~m}^{2} /$ det, maka perubahan jumlah massa zat pada reaktor sepanjang $x=[0,10]$ dapat dilihat seperti gambar di bawah ini:

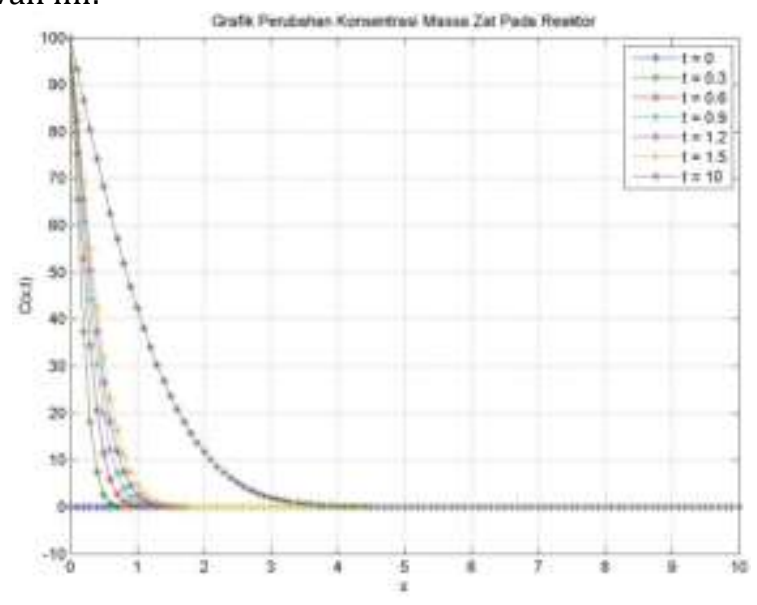

(a)

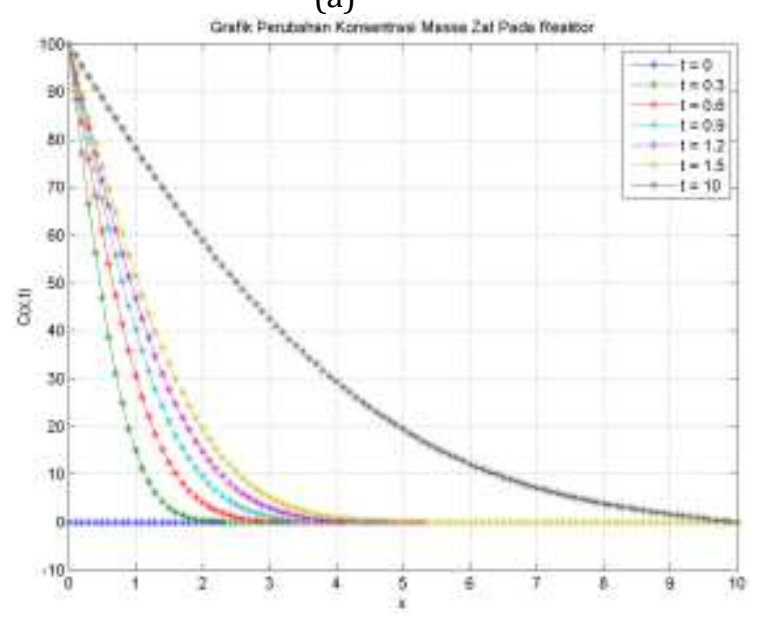

(b)

Gambar 1. (a) Perubahan Konsentrasi Zat dengan $D=0.083 \mathrm{~m}^{2} /$ det (b) Perubahan Konsentrasi Zat dengan $D=0.8 \mathrm{~m}^{2} /$ det 
Gambar 1.a menunjukkan grafik perubahan konsentrasi massa zat dengan memperlambat penyebaran zat di dalam reaktor. Sedangkan Gambar 1.b menyatakan perubahan konsentrasi massa zat dengan mempercepat penyebaran zat di dalam reaktor. Dari kedua gambar di atas, dapat diketahui bahwa semakin cepat zat yang menyebar pada reaktor maka semakin sedikit konsentrasi zat yang mengalami perubahan. Begitupun sebaliknya, semakin lambat zat yang menyebar pada reaktor, maka semakin banyak jumlah konsentrasi zat yang mengalami perubahan.

Selanjutnya, dengan parameter $C_{\text {in }}=$ $100 \mathrm{~mol} / \mathrm{m}^{3}, \quad D=0.083 \mathrm{~m}^{2} /$ det, dan $U=$ $0.008 \mathrm{~m} / \mathrm{det}$, maka perubahan konsentrasi massa zat dengan memperbesar dan memperkecil koefesien reaksi zat $(\gamma)$, dapat dilihat seperti gambar di bawah ini:

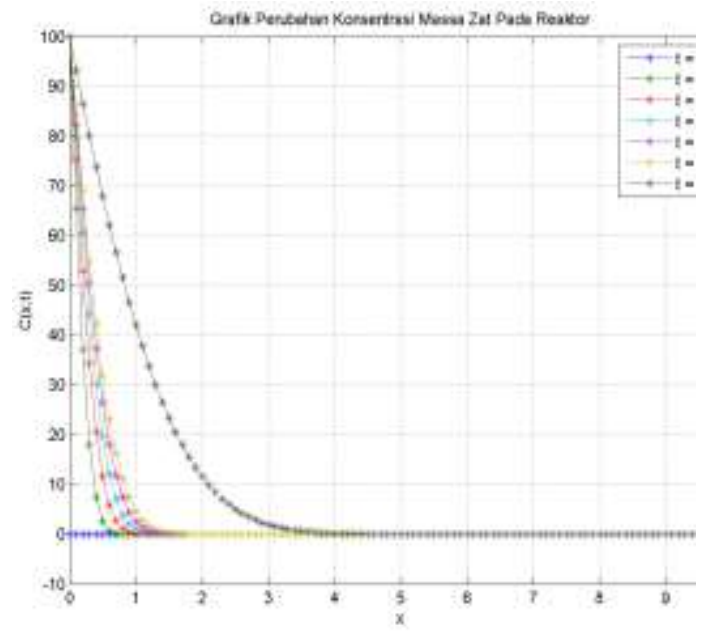

(a)

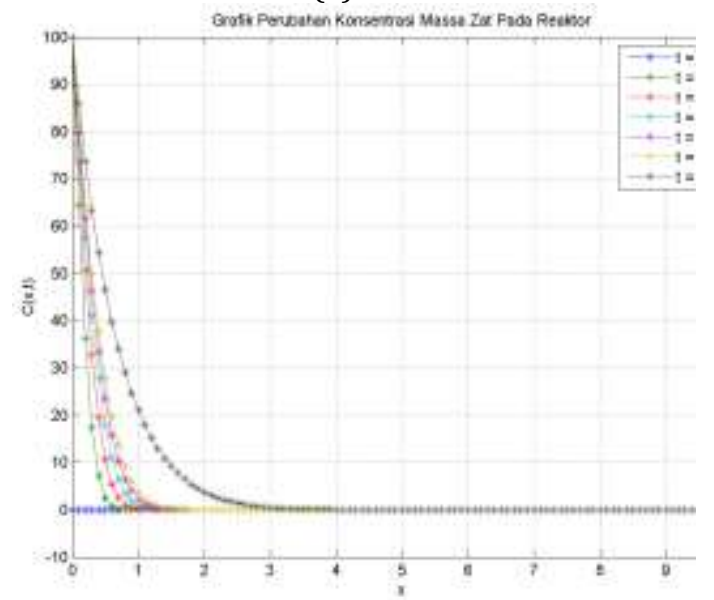

(b)

Gambar 2. (a) Perubahan Konsentrasi Zat dengan $\gamma=0.2 \mathrm{~mol} / \operatorname{det}(\mathrm{b})$ Perubahan

Konsentrasi Zat dengan $0.02 \mathrm{~mol} / \mathrm{det}$

Gambar 2.a menunjukkan grafik perubahan konsentrasi massa zat dengan memperkecil koefisien reaksi zat di dalam reaktor. Sedangkan Gambar 2.b menyatakan perubahan konsentrasi massa zat dengan memperbesar koefisien reaksi zat di dalam reaktor. Dari Gambar 2.a dan 2.b, dapat diketahui bahwa semakin besar koefisien reaksi zat pada reaktor maka semakin banyak konsentrasi zat yang mengalami perubahan di sepanjang reaktor. Begitupun sebaliknya, semakin kecil koefisien reaksi zat pada reaktor, maka semakin sedikit jumlah konsentrasi zat yang mengalami perubahan di sepanjang reaktor.

Pada gambar (1) sampai dengan (2), parameter yang digunakan memenuhi kondisi $U^{2}+4 D \gamma>0$. Parameter yang memenuhi kondisi $U^{2}+4 D \gamma=0$ dan $U^{2}+4 D \gamma<0$ dapat dilihat seperti gambar (3) di bawah ini:

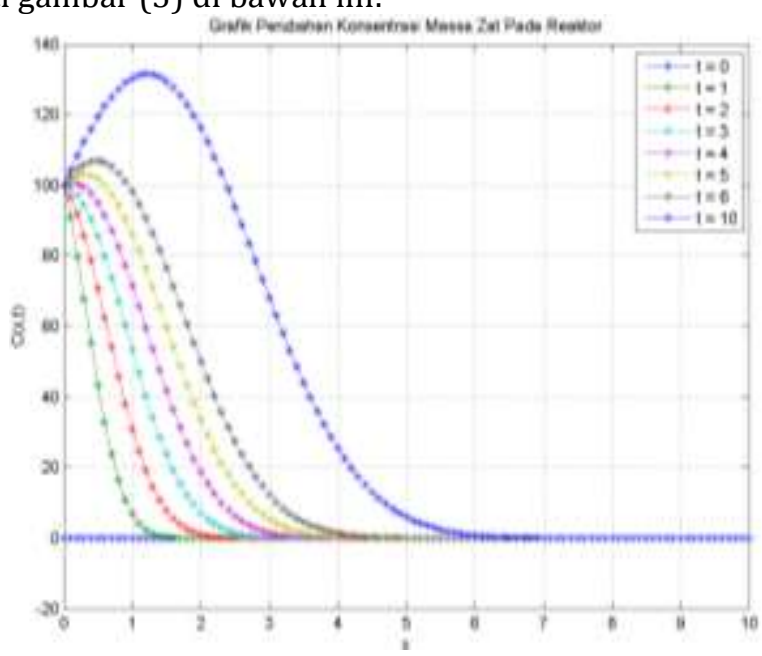

(a)

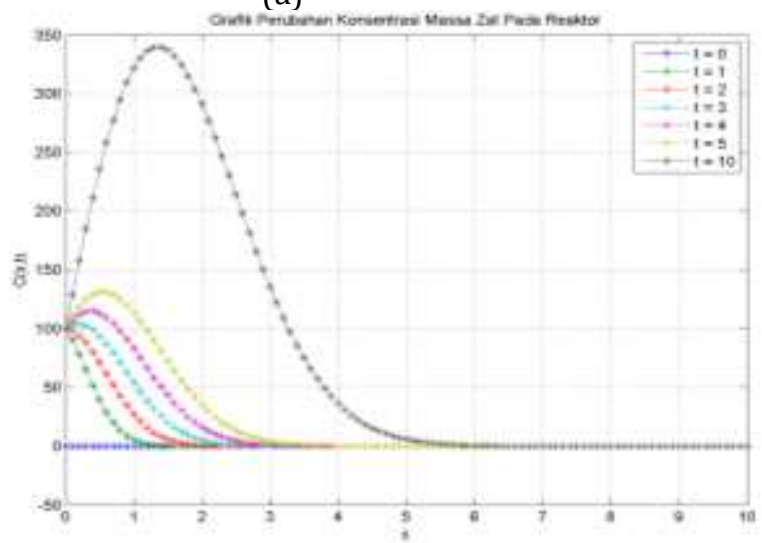

(b)

Gambar 3. (a) Perubahan Konsentrasi Massa Zat dengan $U^{2}+4 D \gamma=0$ (b) Perubahan Konsentrasi Massa Zat dengan $U^{2}+4 D \gamma<0$

Dari gambar 3.a dan 3.b, dapat diketahui pemilihan parameter yang memenuhi $U^{2}+4 D \gamma=$ 0 membutuhkan waktu lebih lama dari pada kondisi $U^{2}+4 D \gamma>0$ untuk mencapai kondisi steady-state, sedangkan pemilihan parameter yang memenuhi $U^{2}+4 D \gamma<0$ membutuhkan waktu paling lama untuk mencapai kondisi steady-state.

Perubahan massa zat dengan parameter yang sama seperti pada Gambar 2.b, selama kurun waktu 15 detik dapat dilihat melalui gambar di bawah ini: 


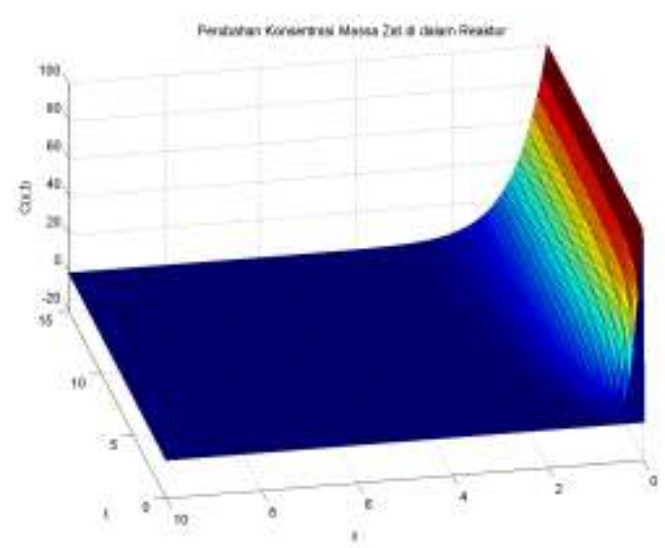

Gambar 3. Perubahan Konsentrasi Massa Zat Selama Kurun Waktu 15 Detik

\section{KESIMPULAN}

Faktor pemilihan parameter yang sedemikian sehingga $U^{2}+4 D \gamma>0$, paling efesien digunakan untuk menyelesaikan permasalahan terkait perubahan konsentrasi massa zat pada suatu raktor. Dengan demikian, semakin cepat zat yang menyebar pada reaktor, maka semakin sedikit jumlah konsentrasi massa zat yang mengalami perubahan; semakin besar koefisien reaksi zat dalam reaktor, maka semakin banyak jumlah konsentrasi massa zat yang mengalami perubahan di sepanjang reaktor.

\section{DAFTAR PUSTAKA}

[1] B. Barnes and G. R. Fulford, Mathematical Modelling with Case Studies A Differential Equation Using Maple and Matlab Second Edition, London: CRC Press, 2009.

[2] W. A. Strauss, Partial Differential Equation An Introduction, Singapore: John Wiley \& Sons.Inc, 1992.

[3] J. Caldwell, Mathematical Modelling Case Studies and Projects, New York: Kluwer Academic Publishers, 2004.

[4] W. E. Boyce and R. C. DiPrima, Elementarry Differential Equation and Boundary Value Proplem Ninth Edition, USA: John Wiley \& Sons, Inc, 2009.

[5] M. A. Pinsky, Partial Differential Equation and Boundary-Value Problem With Aplication Third Edition, Rhode Island: Waveland Press, 2003.

[6] R. P. Agarwal and D. O'Regan, Ordinary and Partial Differential Equation With Special Function, Fourier Series and Boundary Value Problems, New York: Spinger Scince + Business Media, 2009. 